\title{
Thermodynamic analysis on Microwave Plasma Gasification Performance of Sawdust
}

\author{
Aytaç ŞANLISOY, Melda Ö. ÇARPINLIOĞLU \\ *Faculty of Engineering, Department of Mechanical Engineering, Gaziantep University, Turkey
}

\begin{abstract}
In this study, the thermodynamic performance of hornbeam sawdust (HSD) is examined regarding to content conversion performance, system energy efficiency and hot gas efficiency. The thermodynamic performance of hornbeam sawdust in case of 50 and $100 \mathrm{sL} / \mathrm{min}$ air flow rate and varied powers between $3 \mathrm{~kW}$ and $6 \mathrm{~kW}$ is presented. The syngas content conversion performance of hornbeam sawdust is varied between $336 \%$ and $604 \%$. The system energy efficiency of hornbeam sawdust is varied between $20.6 \%$ and $32.57 \%$. The hot gas efficiency of sawdust is varied between $28.1 \%$ and $46.31 \%$.
\end{abstract}

Key words: Plasma, syngas, system efficiency, hot gas efficiency,

\section{Introduction}

Plasma gasification; powered by an external energy source, operates at very high temperatures in an oxygen starved environment to decompose input waste material down to elemental molecules. Products are syngas and inert vitreous (glass-like) materials. The final products can be used to generate electricity or liquid fuel production. Plasma gasification system consists of gasification furnace; feeding system; equipment to handle the slug, ash, tar and char; syngas treatment system; and a monitoring and control system. Thermal plasma gasification performance can change depending on the plasma power [1,2], reactor temperature [3], plasma gases flow rate and type of plasma gases [4], and residence time of material in reactor [5], size and type of material [6-8] and moisture content in the reactor [9]. Gasification process is a thermochemical process and the performance of plasma gasification systems can be evaluated in terms of thermodynamic analysis.

In this study, the thermodynamic analysis of hornbeam sawdust gasification performance is examined. For the modelling of the process, the reactor is chosen as control volume and the syngas content conversion performance, the system energy efficiency and the hot gas efficiency are defined and the effects of plasma power from $3 \mathrm{~kW}$ to $6 \mathrm{~kW}$ and air flow rate from $50 \mathrm{sL} / \mathrm{min}$ to $100 \mathrm{sL} / \mathrm{min}$ are examined.

\section{Materials and Method}

Microwave plasma gasification system MCw Gasifier (Figure 1) consists of the following subcomponents; Microwave plasma system, solid waste feeding and fluid supply systems, gasification

*Corresponding author: Aytaç Şanlısoy Address: Faculty of Engineering, Department of Mechanical Engineering, Gaziantep University, Turkey. E-mail address: aytacsanlisoy@gmail.com, Phone: +903423171591 
reactor, process outputs collection system and the measurement - data acquisition system. The experimental system explanation is also given in the presented papers [10-12]. For the thermodynamic evaluation of gasification system the gasification reactor is chosen as control volume. The mass and energy balance equations are derived for the system. The air flow supplied to the reactor at steady conditions. Also, the plasma heats the reactor with steady power. However, the $250 \mathrm{~g}$ of sawdust dosed to the reactor in each case. The sawdust is handled in the reactor at and adequate time period. Because of the time dependent handling of fuel in the reactor, the system is analyzed by transient process equations as given in thesis of author [13] and project report of authors [14].

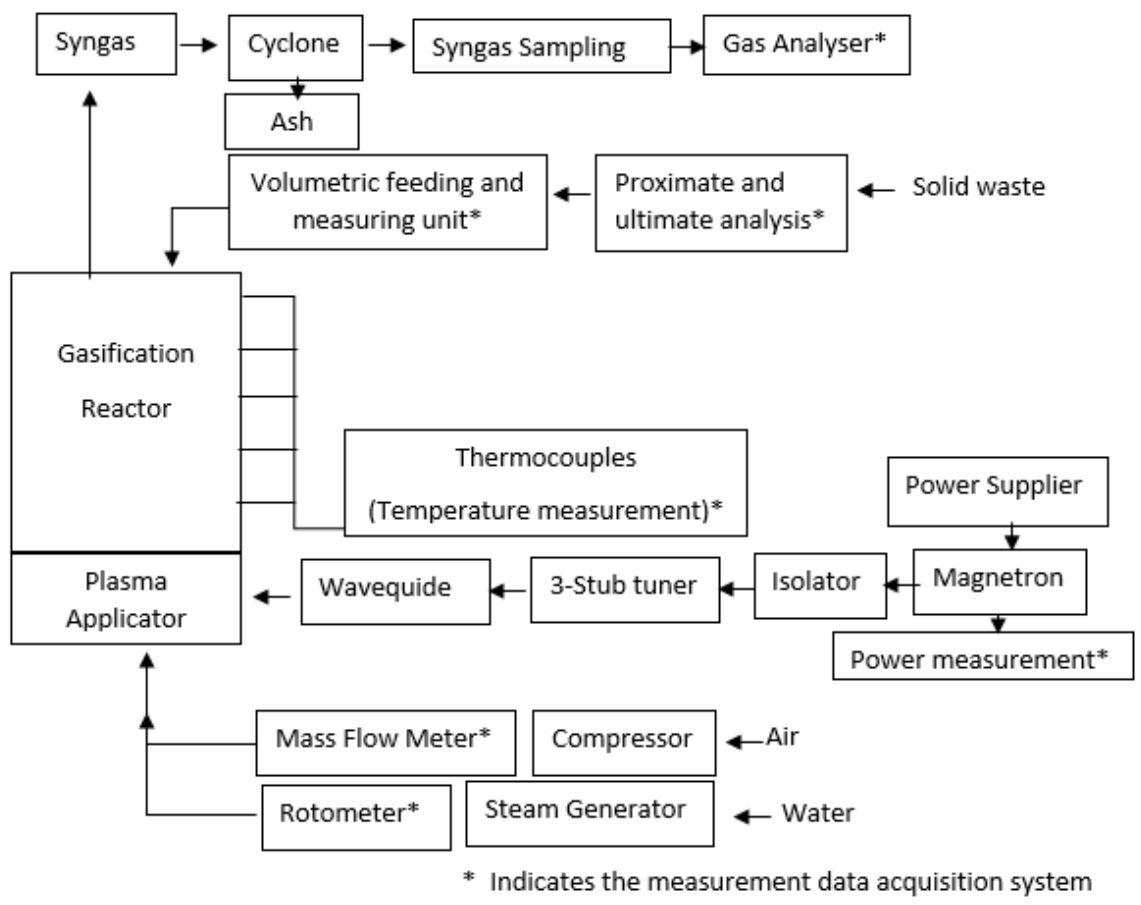

Figure 1. Block diagram of MCw Gasifier

\subsection{Mass balance in gasification reactor}

In order to determine the energy content of individual species, the mass balance should be referred in equation 1:

$m_{\text {input }}-m_{\text {output }}=\left(m_{2}-m_{1}\right)_{C V}(k g)$

The mass balance defined above on a conceptual basis can be expressed in equation 2:

$m_{\text {air }}-m_{\text {syn }}-m_{\text {ash }}=\left(0-m_{f u e l}\right)_{C V}(k g)$ 
$m_{\text {fuel }}+m_{\text {air }}=m_{\text {syn }}+m_{\text {ash }}(\mathrm{kg})$

The process performance is directly related to the decomposition of hornbeam sawdust into its end products of syngas and ash. Since the profit or the required output is syngas, content conversion performance for the syngas $\left(\mathrm{CCP}_{\text {syn }}\right)$ can be defined in terms of syngas mass $\left(m_{\text {syn }}\right)$ and mass of hornbeam sawdust, $\left(m_{\text {fuel }}\right)$ as follows in equation 3 :

$C C P_{\text {syn }}[\%]=\frac{m_{\text {syn }}}{m_{\text {fuel }}} \times 100$

\subsection{Energy efficiency of gasification reactor}

All the input and output energy forms should be defined to write the efficiency terms. There are hornbeam sawdust and plasma energy as input energy while the output is the syngas. In here, the ash is disregarded because of negligible amount of energy content, the air supply is not taken into consideration because of the supplying air in ambient conditions. Heat transfer from reactor is not defined because it is in irreversibility part and causes the reduction of efficiency. The methodology presented here to evaluate the gasification of sawdust is given in details in the other study of authors [15].

The definition of syngas energy and fuel energy are given in equation 4 and 5 . The input plasma energy is given in equation 6:

$$
\begin{aligned}
& E_{\text {syn }}(k J)=m_{\text {syn }}(\mathrm{kg}) \cdot H H V_{\text {syn }}(\mathrm{kJ} / \mathrm{kg}) \\
& E_{\text {fuel }}(\mathrm{kJ})=m_{\text {fuel }}(\mathrm{kg}) \cdot H H V_{\text {fuel }}(\mathrm{kJ} / \mathrm{kg}) \\
& E_{\text {plasma }}(\mathrm{kJ})=W_{\text {plasma }}(\mathrm{kW}) \cdot \mathrm{t}_{\mathrm{g}}(\mathrm{s})
\end{aligned}
$$

The heating value of gas spaces are tabulated in thermodynamic textbook. The related gases heating value is given in Table 1.

Table 1. Heating values of gas species at $25^{\circ} \mathrm{C}$ (taken from Cengel and Boles, 2007 [16])

\begin{tabular}{|l|l|l|}
\hline Substances & HHV $(\mathrm{kJ} / \mathrm{kg})$ & LHV $(\mathrm{kJ} / \mathrm{kg})$ \\
\hline $\mathrm{CO}$ & 10,100 & 10,100 \\
\hline $\mathrm{H}_{2}$ & 141,800 & 120,000 \\
\hline $\mathrm{CH}_{4}$ & 55,530 & 50,050 \\
\hline $\mathrm{C}_{2+}$ & 50,900 & 48,000 \\
\hline
\end{tabular}


Since energy efficiency parameters are based upon the determination of higher heating value (HHV); HHV of the sawdust can be calculated by using equation 7 described by Channiwala and Parikh, 2002 [17].

$H H V=0.3491 C+1.1783 H+0.1005 S-0.10340-0.0151 N-0.0211 a s h\left(\frac{M J}{k g}\right)$

In this equation, $\mathrm{C}, \mathrm{H}, \mathrm{S}, \mathrm{O}, \mathrm{N}$ and ash are the weight percentage of carbon, hydrogen, Sulphur, oxygen, nitrogen and ash respectively. The weight percentage of these elements is determined by proximate and ultimate analysis and results are presented in the following section. The measurement methodology is also presented in authors paper [11].

System energy efficiency is defined in equation 8.

$\eta_{E S}[\%]=\frac{E_{\text {syn }}(k J)}{E_{\text {fuel }}(k J)+E_{\text {plasma }}(k J)} \times 100$

In these efficiency definitions, the temperature of the syngas $\left(\mathrm{T}_{\text {syn }}\right)$ or the sensible energy level of the syngas is the critical parameter. Hot gas efficiency $\left(\eta_{\mathrm{HG}}\right)$ is taken into account for the cases of syngas temperature $\left(\mathrm{T}_{\text {syn }}\right)$ is higher than the ambient temperature $\left(\mathrm{T}_{0}\right)$. The system hot gas efficiency $\left(\eta_{\mathrm{HG}}\right)$ is given in equation 9 . The syngas temperature for the power and air flow rate are presented in results section.

$\eta_{H G}[\%]=\frac{E_{\text {syn }}(k J)+m_{\text {syn }}(\mathrm{kg}) \cdot\left[c_{p(s y n)}(\mathrm{kJ} / \mathrm{kg.K}) \cdot\left(T_{\text {syn }}-T_{o}\right)(K)\right]}{E_{\text {fuel }}(k J)+E_{\text {plasma }}(k J)} \times 100$

\section{Results}

In this study, the hornbeam sawdust is taken as fuel for the plasma gasification. The proximate and ultimate analysis are given in Table 2.

Table 2. Proximate and ultimate analysis of the hornbeam sawdust

\begin{tabular}{|l|l|l|l|l|l|}
\hline Solid fuel & Moisture (\%) & Volatile matter (\%) & Fixed carbon (\%) & Ash (\%) & \\
\hline Hornbeam sawdust & 17.39 & 72.58 & 10.02 & 0.69 & \\
\hline Solid fuel & Carbon (\%) & Hydrogen (\%) & Oxygen (\%) & $\begin{array}{l}\text { Nitrogen } \\
\text { (\%) }\end{array}$ & $\begin{array}{l}\text { Sulphur } \\
\text { (\%) }\end{array}$ \\
\hline Hornbeam sawdust & 36.15 & 6.24 & 56.92 & 0.00 & 0.00 \\
\hline
\end{tabular}


The variation of syngas temperature, supplied air amount, produced syngas amount, syngas content by changing power and air flow rate is given in Table 3 . The syngas temperature increases by rising up the plasma power.

Table 3. Variation of syngas temperature, air amount, syngas amount and syngas content by changing plasma power and air flow rate

\begin{tabular}{|c|c|c|c|c|c|c|c|c|c|c|}
\hline & $\begin{array}{l}\text { Power } \\
\text { (W) }\end{array}$ & $\begin{array}{c}\mathrm{T}_{\text {syn }} \\
{ }^{\circ} \mathrm{C}\end{array}$ & $\begin{array}{l}\mathrm{m}_{\text {air }} \\
(\mathrm{kg})\end{array}$ & $\begin{array}{c}\mathrm{m}_{\text {syngas }} \\
\text { (kg) }\end{array}$ & $\begin{array}{c}\mathrm{O}_{2}, \\
\%\end{array}$ & $\begin{array}{c}\mathrm{CO}_{2}, \\
\%\end{array}$ & $\begin{array}{c}\mathrm{CO}, \\
\%\end{array}$ & $\mathrm{H}_{2}, \%$ & $\begin{array}{c}\mathrm{CH}_{4}, \\
\%\end{array}$ & $\mathrm{~N}_{2}, \%$ \\
\hline \multirow{6}{*}{$\begin{array}{l}\text { Hornbeam } \\
\text { sawdust- } \\
50 \mathrm{sL} / \mathrm{min}\end{array}$} & 3000 & 759 & 0.87 & 1.12 & 0.73 & 24.73 & 6.87 & 0.16 & 1.00 & 66.51 \\
\hline & 3600 & 831 & 0.81 & 1.06 & 0.85 & 21.03 & 8.70 & 0.31 & 1.02 & 68.09 \\
\hline & 4200 & 915 & 0.79 & 1.04 & 0.92 & 17.63 & 9.13 & 0.36 & 1.02 & 70.93 \\
\hline & 4800 & 1007 & 0.71 & 0.96 & 0.78 & 17.63 & 14.12 & 0.40 & 1.04 & 66.02 \\
\hline & 5400 & 1096 & 0.67 & 0.92 & 0.96 & 17.25 & 15.39 & 0.49 & 1.04 & 64.86 \\
\hline & 6000 & 1175 & 0.59 & 0.84 & 1.04 & 16.94 & 19.48 & 0.64 & 1.06 & 60.86 \\
\hline \multirow{6}{*}{$\begin{array}{l}\text { Hornbeam } \\
\text { sawdust- } \\
100 \mathrm{sL} / \mathrm{min}\end{array}$} & 3000 & 621 & 0.63 & 0.88 & 1.25 & 31.82 & 4.28 & 0.13 & 1.21 & 61.32 \\
\hline & 3600 & 762 & 0.59 & 0.84 & 1.30 & 30.85 & 5.04 & 0.26 & 1.21 & 61.34 \\
\hline & 4200 & 887 & 0.55 & 0.80 & 1.34 & 30.55 & 5.54 & 0.28 & 1.20 & 61.07 \\
\hline & 4800 & 937 & 0.51 & 0.76 & 1.42 & 29.63 & 6.02 & 0.35 & 1.19 & 61.38 \\
\hline & 5400 & 1008 & 0.44 & 0.69 & 1.41 & 26.70 & 7.66 & 0.40 & 1.19 & 62.64 \\
\hline & 6000 & 1129 & 0.41 & 0.66 & 1.50 & 25.22 & 9.39 & 0.48 & 1.22 & 62.19 \\
\hline
\end{tabular}

Because the energy density in the medium increases by increase of power. However, the increase of air flow rate reduces the syngas temperature. The supplied air amount reduces by increase of plasma power. The increase of plasma power reduces the gasification duration and air is supplied to the reactor steadily. This fact reduces the produced syngas amount too. Because the produced syngas amount is consist of fuel and air. The supplied fuel is constant in all the cases $(250 \mathrm{~g})$. The syngas production decreases approximately $25 \%$ by increasing the plasma power from $3 \mathrm{~kW}$ to 6 $\mathrm{kW}$. Similarly, the increase of air flow rate also effects the supplied air amount and produced syngas adversely even the supplied air flow rate rises. Because, the increase of air flow rate is also reduces the gasification duration significantly. The reduction in the syngas production is $21.43 \%$ when the flow rate increases from $50 \mathrm{sL} / \mathrm{min}$ to $100 \mathrm{sL} / \mathrm{min}$. As quantity of syngas production varies with plasma power and air flow rate, the quality of syngas varies by changing plasma power and air flow rate too. The $\mathrm{O}_{2}$ percentage in syngas increases approximately $42 \%, \mathrm{CO}_{2}$ percentage in syngas reduces approximately $31.5 \%$, CO percentage in syngas increases approximately 131 $\%, \mathrm{H}_{2}$ percentage in syngas increases approximately $183 \%, \mathrm{CH}_{4}$ percentage in syngas increases approximately $6 \%$ and $\mathrm{N}_{2}$ percentage in syngas reduces approximately $8.5 \%$ by increasing power from $3 \mathrm{~kW}$ to $6 \mathrm{~kW}$ at $50 \mathrm{sL} / \mathrm{min}$ air flow rate. The $\mathrm{O}_{2}$ percentage in syngas increases approximately $20 \%, \mathrm{CO}_{2}$ percentage in syngas reduces approximately $20 \%$, CO percentage in syngas increases approximately $119 \%, \mathrm{H}_{2}$ percentage in syngas increases approximately $269 \%, \mathrm{CH}_{4}$ percentage in syngas increases approximately $0.8 \%$ and $\mathrm{N}_{2}$ percentage in syngas increases approximately $1.4 \%$ by increasing power from $3 \mathrm{~kW}$ to $6 \mathrm{~kW}$ at $100 \mathrm{sL} / \mathrm{min}$ air flow rate. The $\mathrm{O}_{2}$ percentage in syngas increases approximately $44 \%, \mathrm{CO}_{2}$ percentage in syngas increases approximately $49 \%, \mathrm{CO}$ percentage in syngas decreases approximately $52 \%, \mathrm{H}_{2}$ percentage in syngas reduces approximately $25 \%, \mathrm{CH}_{4}$ percentage in syngas increases approximately $21 \%$ and $\mathrm{N}_{2}$ percentage 
in syngas reduces approximately $7.8 \%$ by increasing air flow rate from $50 \mathrm{sL} / \mathrm{min}$ to $100 \mathrm{sL} / \mathrm{min}$ at $3 \mathrm{~kW}$ plasma power. The $\mathrm{O}_{2}$ percentage in syngas increases approximately $71 \%, \mathrm{CO}_{2}$ percentage in syngas increases approximately $29 \%$, CO percentage in syngas decreases approximately $38 \%$, $\mathrm{H}_{2}$ percentage in syngas reduces approximately $19 \%, \mathrm{CH}_{4}$ percentage in syngas increases approximately $15 \%$ and $\mathrm{N}_{2}$ percentage in syngas reduces approximately $2.1 \%$ by increasing air flow rate from $50 \mathrm{sL} / \mathrm{min}$ to $100 \mathrm{sL} / \mathrm{min}$ at $6 \mathrm{~kW}$ plasma power.

Variation of syngas content conversion performance, syngas energy, fuel energy, plasma energy, system energy efficiency and hot gas efficiency by changing plasma power and air flow rate are given in Table 4 . The content conversion performance of syngas $\left(\mathrm{CCP}_{\text {syn }}\right)$ reduces approximately $32 \%$ in case of $50 \mathrm{sL} / \mathrm{min}$ air flow rate and $40 \%$ in case of $100 \mathrm{sL} / \mathrm{min}$ air flow rate by increasing the plasma power from $3 \mathrm{~kW}$ to $6 \mathrm{~kW}$. On the other hand, the increasing air flow rate enhanced the content conversion performance of syngas $\left(\mathrm{CCP}_{\text {syn }}\right)$. The increment in the content conversion performance of syngas $\left(\mathrm{CCP}_{\text {syn }}\right)$ is $35 \%$ for $3 \mathrm{~kW}$ and $28 \%$ for $6 \mathrm{~kW}$ when the flow rate increases from $50 \mathrm{sL} / \mathrm{min}$ to $100 \mathrm{sL} / \mathrm{min}$. The highest content conversion performance of syngas $\left(\mathrm{CCP}_{\text {syn }}\right)$ is $604 \%$ at $3 \mathrm{~kW}$ plasma power, $100 \mathrm{sL} / \mathrm{min}$ while the lowest content conversion performance of syngas $\left(\mathrm{CCP}_{\text {syn }}\right)$ is $336 \%$ at $6 \mathrm{~kW}$ plasma power, $50 \mathrm{sL} / \mathrm{min}$. The system energy efficiency $\left(\eta_{E S}\right)$ goes up approximately $37 \%$ in case of $50 \mathrm{sL} / \mathrm{min}$ air flow rate, and $15 \%$ in case of 100 $\mathrm{sL} / \mathrm{min}$ air flow rate by increasing the plasma power from $3 \mathrm{~kW}$ to $6 \mathrm{~kW}$. Also, the increment in the system energy efficiency $\left(\eta_{\mathrm{ES}}\right)$ is $29.6 \%$ for $3 \mathrm{~kW}$ plasma power and it reduces $3.6 \%$ for 6 $\mathrm{kW}$ plasma power when the flow rate increases from $50 \mathrm{sL} / \mathrm{min}$ to $100 \mathrm{sL} / \mathrm{min}$. While the highest system energy efficiency $\left(\eta_{\mathrm{ES}}\right)$ is $32.57 \%$ at $6 \mathrm{~kW}$ plasma power and $50 \mathrm{sL} / \mathrm{min}$ air flow rate, the lowest system energy efficiency $\left(\eta_{\mathrm{ES}}\right)$ is $20.6 \%$ at $3 \mathrm{~kW}$ plasma power and $50 \mathrm{sL} / \mathrm{min}$ air flow rate.

Table 4. Variation of syngas content conversion performance, syngas energy, fuel energy, plasma energy, system energy efficiency and hot gas efficiency by changing plasma power and air flow rate.

\begin{tabular}{|c|c|c|c|c|c|c|c|}
\hline & $\begin{array}{l}\text { Power } \\
\text { (W) }\end{array}$ & $\begin{array}{l}\mathrm{CCP}_{\text {syn }} \\
(\%)\end{array}$ & $\begin{array}{l}\text { Syngas } \\
\text { energy }(k J)\end{array}$ & $\begin{array}{l}\text { Fuel energy } \\
(\mathrm{kJ})\end{array}$ & $\begin{array}{l}\text { Plasma energy } \\
(\mathrm{kJ})\end{array}$ & $\eta_{\mathrm{ES}}[\%]$ & $\eta_{\mathrm{HG}}[\%]$ \\
\hline \multirow{6}{*}{$\begin{array}{l}\text { Hornbeam } \\
\text { sawdust- } \\
50 \mathrm{sL} / \mathrm{min}\end{array}$} & 3000 & 446 & 1643.98 & \multirow{12}{*}{5338.23} & 2640.00 & 20.64 & 28.10 \\
\hline & 3600 & 423 & 1985.28 & & 2952.00 & 23.90 & 32.03 \\
\hline & 4200 & 415 & 2078.47 & & 3360.00 & 23.90 & 32.93 \\
\hline & 4800 & 383 & 2464.50 & & 3456.00 & 27.97 & 37.70 \\
\hline & 5400 & 368 & 2602.79 & & 3672.00 & 28.89 & 39.43 \\
\hline & 6000 & 336 & 2903.46 & & 3600.00 & 32.57 & 43.59 \\
\hline \multirow{6}{*}{$\begin{array}{l}\text { Hornbeam } \\
\text { sawdust- } \\
100 \mathrm{sL} / \mathrm{min}\end{array}$} & 3000 & 604 & 1935.86 & & 1920.00 & 26.75 & 34.19 \\
\hline & 3600 & 573 & 2227.48 & & 2160.00 & 29.71 & 40.15 \\
\hline & 4200 & 541 & 2203.98 & & 2352.00 & 28.62 & 41.28 \\
\hline & 4800 & 509 & 2242.27 & & 2496.00 & 28.56 & 41.48 \\
\hline & 5400 & 454 & 2280.28 & & 2430.00 & 29.24 & 42.44 \\
\hline & 6000 & 431 & 2479.18 & & 2520.00 & 31.38 & 46.31 \\
\hline
\end{tabular}

The hot gas efficiency $\left(\eta_{\mathrm{HG}}\right)$ increases approximately $35 \%$ in case of $50 \mathrm{sL} / \mathrm{min}$ air flow rate and $26 \%$ in case of $100 \mathrm{sL} / \mathrm{min}$ air flow rate by increasing the plasma power from $3 \mathrm{~kW}$ to $6 \mathrm{~kW}$. Also, 
the increment in the hot gas efficiency $\left(\eta_{\mathrm{HG}}\right)$ is $22 \%$ for $3 \mathrm{~kW}$ plasma power and it rises $6.2 \%$ for $6 \mathrm{~kW}$ plasma power when the flow rate increases from $50 \mathrm{sL} / \mathrm{min}$ to $100 \mathrm{sL} / \mathrm{min}$. While the highest hot gas efficiency $\left(\eta_{\mathrm{HG}}\right)$ is $46.31 \%$ at $6 \mathrm{~kW}$ plasma power and $100 \mathrm{sL} / \mathrm{min}$, the lowest hot gas efficiency $\left(\eta_{\mathrm{HG}}\right)$ is $28.1 \%$ at $3 \mathrm{~kW}$ plasma power, $50 \mathrm{sL} / \mathrm{min}$.

\section{Discussion}

The syngas temperature increases by increase of plasma power while it reduces by increasing the air flow rate. Because the energy density in the plasma region is the critical. When the power increases, the energy density rises in plasma region but increasing air flow rate reduces the energy density and lowers the temperature. The produced syngas amount depends on the supplied air amount, plasma power and gasification duration. When the power increases, the gasification time reduces and it lowers the syngas production. Similarly, increasing air flow rate lowers the gasification duration. The reduction in gasification time also lowers the supplied air amount to the reactor and it affects the produced syngas amount reversely. Syngas energy rises by increase of plasma power. Because the temperature and energy density of the medium gases increase. On the other hand, the air flow rate has reverse effect on the syngas energy. Increasing plasma power also increases the system energy efficiency and hot gas efficiency even the supplied plasma power (consumption) increases. Because the syngas energy is effected much more with plasma power. Also, the supplied air flow rate effects the system energy efficiency and hot gas efficiency favourably.

\section{Conclusions}

In this study, thermodynamic performance parameters; syngas content conversion performance, system energy efficiency and hot gas efficiency are defined. The effects of air flow rate and plasma power on plasma gasification performance are revealed. The syngas content conversion performance of hornbeam sawdust is varied between $336 \%$ and $604 \%$. The system energy efficiency of hornbeam sawdust is varied between $20.6 \%$ and $32.57 \%$. The hot gas efficiency of sawdust is varied between $28.1 \%$ and $46.31 \%$.

\section{Acknowledgements}

The authors would like to acknowledge the financial support of this work by the Scientific and Technological Research Council of Turkey (TUBITAK) under the contract number 115M389. Also, authors are thankful for the financial support of University of Gaziantep BAP -RM16.01. 


\section{References}

[1] Yoon SJ, Yun YM, Seo MW, Kim YK, Ra HW, Lee J-G. Hydrogen and syngas production from glycerol through microwave plasma gasification. International Journal of Hydrogen Energy 2013:38:14559-67.

[2] $\mathrm{Tu} \mathrm{W}-\mathrm{K}$, et al. Products and bioenergy from the pyrolysis of rice straw via radio frequency plasma and its kinetics. Bioresource Technology 2009:100:2052-61.

[3] Uhm HS, Kwak HS, Hong YC. Carbon dioxide elimination and regeneration of resources in a microwave plasma torch. Environmental Pollution 2016:211:191-7.

[4] Hong YC, Lee SJ, Shin DH, Kim YJ, Lee BJ, Cho SY, Chang HS. Syngas production from gasification of brown coal in a microwave torch plasma. Energy 2012:47:36-40.

[5] Yoon SJ, Lee J-G. Hydrogen-rich syngas production through coal and charcoal gasification using microwave steam and air plasma torch. International Journal of Hydrogen Energy 2012:37:17093-100.

[6] Huang H, Tang L. Pyrolysis treatment of waste tire powder in a capacitively coupled RF plasma reactor. Energy Conversion and Management 2009:50:611-7.

[7] Lee HG, Park H-W, Choi S, Park H-S, Park D-W. Production of Synthesis Gas from Coal by DC Non-Transferred Steam Plasma Gasification System. Journal of Chemical Engineering of Japon 2014:47:334-9.

[8] Hlina M, Hrabovsky M, Kavka T, Konrad M. Production of high quality syngas from argon/water plasma gasification of biomass and waste. Waste Management 2014:34:63-6.

[9] Shie J-L, Chen L-X, Lin K-L, Chang C-Y. Plasmatron gasification of biomass lignocellulosic waste materials derived from municipal solid waste. Energy 2014:66:82-9.

[10] Sanlisoy A, Carpinlioglu MO, Presentation of a Microwave Plasma Gasification System "MCw Gasifier" in Fourth European Conference on Renewable Energy Systems (ECRES2016). 2016: Istanbul. p. 503-6.

[11] Sanlisoy A, Melez H, Carpinlioglu MO. Characteristics of the Solid Fuels for the Plasma Gasification. Energy Procedia 2017:141:282-6.

[12] Sanlisoy A, Carpinlioglu MO. Preliminary measurements on microwave plasma flame for gasification. Energy, Ecology and Environment 2017:

[13] Sanlisoy A, An Experimental Investigation on Design and Performance of Plasma Gasification Systems, in Mechanical Engineering Department of Gaziantep University. 2018, Gaziantep University.

[14] Çarpınlığlu MÖ. Katı Atıkların Enerji Dönüşümünde Plazma Gazlaştırma Kullanımı ile Çalışan Laboratuvar Ölçekli Bir Test Düzeneğinin (Mikrodalga Gazlaştırıcı) "Mcwgazlaştırıcı" Tasarım Üretim ve Performans Değerlendirilmesi-Plazma Gazlaştırma Teknolojisinin-Bilginin Üretilip Kullanılmasında Bir Vaka TUBITAK 115M389 final report 2018:

[15] Carpinlioglu MO, Sanlisoy A. Performance assessment of plasma gasification for waste to energy conversion: A methodology for thermodynamic analysis. International Journal of Hydrogen Energy 2018:43:11493-504.

[16] Çengel YA, Boles MA, Thermodynamics: an engineering approach. 2007, USA: McGrawHill.

[17] Channiwala SA, Parikh PP. A unified correlation for estimating HHV of solid, liquid and gaseous fuels. Fuel 2002:81:1051-63. 